\title{
Embezzlement of Principal Shareholders Based on a Case Study of Xiancheng Mining Company
}

\author{
Ran Liu* \\ College of Economic Management, Dalian University \\ School of Business Management, Northeastern University \\ Email: liuran100@hotmail.com
}

\author{
Jihui Sun, Lantian Jiang \\ College of Economic Management, Dalian University \\ Dalian 116622, China
}

\begin{abstract}
The consequences and possible reasons for embezzlement of principal shareholders based on Xiancheng mining group were analyzed. According to data from Xiancheng mining group, existing problems of external governance and internal governance causing embezzlement of principal shareholders were pointed out. The study indicates that corporate governance could help to significantly improve internal and external governance structures and reduce tunneling. Principal shareholders should be committed to make better development of the company and improve the company's competitiveness to obtain better prospects. Furthermore, economic reforms like the attempts to improve corporate governance and to limit the influence of the state in publicly listed companies are recommended.
\end{abstract}

Keywords-principal shareholder; corporate governance; operational tunneling

\section{INTRODUCTION}

In China, a series of scandals related to the embezzlement of assets by principal shareholders have been brought to light recently. From the incident of 'Qiongminyuan' in 1997 to the scandal of the 'Sanjiu Group' in 2005, plenty of anecdotal evidence demonstrates the extent with which resources of companies have been abused by principal shareholders. This serious corporate governance problem could hinder economic development1, which raises the question: how to prevent tunneling and protect the interests of small investors. To improve corporate governance, we need to identify which corporate governance mechanisms fail and hence facilitate asset appropriation in China.

Extensive research on the fund embezzlement or tunneling of principal shareholders has been made [1-5]. Shleifer and Vishny [6] detected that when large stockholders control firms, the main problem is no longer the conflict of interests between management and shareholders, but preventing principal shareholders from exploiting minority shareholders. Johnson et al. [7] coined the term 'tunneling' to describe asset appropriation by large shareholders, which legally or illegally transfer assets and profits to themselves. Tunneling not only hurts the interests of small shareholders, but also seriously hinders stock markets' development [8]. Johnson et al. [7] argued that unrestrained tunneling was the main reason for the Asian financial crisis from 1997 to 1999. During financial crises, many facts proved that emerging markets suffer from tunneling more severely than mature markets. To enhance the development of emerging financial markets, one has to identify internal and external governance mechanisms that prevent tunneling. Yet, the interrelation of corporate governance mechanisms and operational tunneling has not been studied. Our paper tries to detect mechanisms and provides policy recommendations to strengthen corporate governance not only in China - but also in other emerging markets.

\section{EMBEZZLEMENT AND ITS CONSEQUENCES}

\section{A. Definition of Embezzlement}

Embezzlement is an act of dishonestly withholding assets for the purpose of conversion (theft) of such assets, by one or more persons to whom the assets were entrusted, either to be held or to be used for specific purposes. Embezzlement is a type of financial fraud, e.g. a lawyer might embezzle funds from the trust accounts of his or her clients; a financial advisor might embezzle the funds of investors; and a husband or a wife might embezzle funds from a bank account jointly held with the spouse. Embezzlement usually is a premeditated crime performed methodically, with the embezzler taking precautions to conceal his or her activities of the criminal conversion of the property of another person, because the embezzlement is occurring without the knowledge or the consent of the affected person.

All too often, inexperienced investors who are looking to make a return on their money are taken advantage of by unscrupulous advisors. Usually, this type of behavior is due to an act of embezzlement. Embezzlement occurs when a trusting investor places money or assets into the care of an individual or company who promises a return on the initial investment. The embezzler will then take steps to make it appear as if the investor's money is guaranteed to provide a significant return. In fact, the embezzler will divert the investment into their own personal accounts. Often, this activity will take place before the investor has a chance to learn the true destination of their funds.

Often it involves the trusted individual embezzling only a small proportion or fraction of the total of the funds or resources he/she receives or controls; in an attempt to minimize the risk of the detection of the misallocation of the funds or resources. When successful, embezzlements continue for years (or even decades) without detection. It is often only when a relatively large proportion of the funds are needed at one time; 
or they are called upon for another use; or, when a major institutional reorganization (the closing or moving of a plant or business office, or a merger/acquisition of a firm) requires the complete and independent accounting of all real and liquid assets; prior to, or concurrent with, the reorganization, that the victims realize the funds, savings, assets or other resources, are missing and that they have been duped by the embezzler.

\section{B. Forms of Embezzlement}

Embezzlement sometimes involves falsification of records in order to conceal the activity. Embezzlers commonly secrete relatively small amounts repeatedly, in a systematic and/or methodical manner, over a long period of time, although some embezzlers secrete one large sum at once. Some very successful embezzlement schemes have continued for many years before being detected due to the skill of the embezzler in concealing the nature of the transactions or their skill in gaining the trust and confidence of investors or clients, who are then reluctant to "test" the embezzler's trustworthiness by forcing a withdrawal of funds.

Embezzling should not be confused with skimming which is under-reporting income and pocketing the difference. For example, in 2005, several managers of the service provider Aramark were found to be under-reporting profits from a string of vending machine locations in the eastern United States. While the amount stolen from each machine was relatively small, the total amount taken from many machines over a length of time was very large. A smart technique employed by many small time embezzlers can be covered by falsifying the records. (Example, by removing a small amount of money and falsifying the record the register would be technically correct, while the manager would remove the profit and leave the float in, this method would effectively make the register short for the next user and throw the blame onto them). Another method is to create a false vendor account, and to supply false bills to the company being embezzled so that the checks that are cut appear completely legitimate. Yet another method is to create phantom employees, who are then paid with payroll checks. The latter two methods should be uncovered by routine audits, but often aren't if the audit is not sufficiently in-depth, because the paperwork appears to be in order. The first method is easier to detect if all transactions are by cheque or other instrument, but if many transactions are in cash, it is much more difficult to identify. Employers have developed a number of strategies to deal with this problem. In fact, cash registers were invented just for this reason.

Some of the most complex (and potentially most lucrative) forms of embezzlement involve Ponzi-like financial schemes where high returns to early investors are paid out of funds received from later investors duped into believing they are themselves receiving entry into a high return investment scheme. The Madoff investment scandal is an example of this kind of high level embezzlement scheme, where it is alleged that $\$ 65$ billion was siphoned off from gullible investors and financial institutions.

\section{Consequences of embezzlement}

Embezzlement can occur at any level of investment but the penalties for this type of fraudulent financial behavior are strict no matter what the degree of investment. However, the penalties for embezzlement will generally increase according to the amount of money or property that has been stolen or the degree to which the investor has been duped. For example, an embezzlement scheme that subverts monetary investments will result in the responsible party being forced to return all misdirected funds to the initial investor. This return of money is known as restitution. Restitution can apply to whatever the investment consisted of originally, from monetary deposits to housing deeds and car titles. In some cases, the restitution amount will be compounded with any interest that would have accrued with the investment or with fees that were spent on lawyers and court proceedings in the process of securing the restitution [9].

If the effects of an embezzlement scheme are severe enough, the guilty party can face serious jail or prison terms as a form of punishment. This punishment can occur if the embezzling party cannot afford to fully pay restitution or if their scheme has resulted in very significant damages. For example, in most states, if the embezzlement amount exceeds $\$ 100,000$, the guilty party can face a prison term of up to 25 years in addition to any and all restitution payments.

\section{POSSIBLE REASONS FOR EMBEZZLEMENT}

\section{A. Current status of embezzlement}

There is a declined trend in embezzlement of principal shareholders of China's listed companies in recent years. It can be seen that the situations on embezzlement of principal shareholders were very serious from the report in 2003. In the report, over 676 of the 1175 listed companies in Shanghai and Shenzhen listed companies experienced the embezzlement of principal shareholders. The proportion of embezzlement of principal shareholders is up to $57 \%$ and the capital amount embezzled is startlingly up to 96.669 billion Chinese Yuan.

\section{B. Possible reasons of embezzlement}

Stake proportion is one of the possible reasons. In general, the rights of shareholders are the same as corporate interests. Similar with the minority shareholders, the embezzlement of the company's liquidity will damage to the equity of the principal shareholders in the company. The shareholding ratio is a very important factor in the embezzlement of principal shareholders. Without considering governance system, if only the shareholding ratio is considered, when the gains from the fund embezzlement is larger than that the loss of the shares held by large shareholders, a tendency to fund embezzlement by large shareholders will decline. Usually large shareholders will decide what most benefit themselves and then how to operate according to the actual situation. For this reason, it can be attributed to the deep moral sense. The effective measure to solve the fund embezzlement of principal shareholders is to improve ideological thoughts of large shareholders and carry out effective governance and supervision to large shareholders.

Information imbalance is also one of the reasons. One of the reasons for the fund embezzlement of principal shareholders is information asymmetry. As a large shareholder, it's a big advantage for major shareholders over minor 
shareholders is that major shareholders are directly involved in decision-making with respect to minor shareholders. They always have access to a certain amount of information, but minor shareholders generally cannot participate in the board. The quality, integrity and time accessing to information are far inferior to the major shareholders. The underlying reason for the company disclosing financial information is to avoid information imbalance and conflicts arising from the agent. The fund embezzlement of principal shareholders not only damage the interests of minority shareholders, but also confuse the sight of the minority shareholders through the disclosure of false information, so that they mistakenly think the company is in good operations. They can only get information from the company's announcement since they lack of channels to collect relevant information due to less shares of minority shareholders. Long this way, the regulatory supervision of major shareholders from shareholders is vacant, so the possibility of fund embezzlement by major shareholders will greatly increase. Thus, standardizing financial, accounting personnel can reduce fund embezzlement of the major shareholders caused by the information imbalance. Accountants should comply with the appropriate professional ethics, refuse to unreasonable demands, and fulfill their respective responsibilities in the production of the annual report and disclosure of information in accordance with the actual situation.

Lack of governance is also one of the reasons. Unlike other countries, there is no explicit regulation that fund embezzlement by major shareholders is illegal in China's "Company Law", thus there is no corresponding law to rely on, and there is no good way to carry out the punishment by regulatory authorities.

China Securities Regulatory Commission has no right to directly punish the major shareholders due to the fund embezzlement. What the Commission has done is to strengthen the management, risk prevention, disclosure of information. In 2009 the Commission clearly regulated that if the listed companies and associated parties undergo funds embezzlement, the information needs to be disclosed in detail in the annual report.

Egoism of principal shareholders is again a reason. Large shareholder capital appropriation acts, the underlying causes are due egoism mischief. Large shareholders and corporate interests should be consistent, do not bother occupation of company funds, do solid work, good for the company's major shareholders can also be profitable. But some of the benefits or reduce the large shareholders in order to obtain more benefits, at embezzlement of company funds, harm the interests of others as well as themselves into a cusp. For example, the former chairman Yin Cheng Mining for their own selfish interests occupy the company's liquidity, caused great impact on the company at the same time, the Commission itself has also been a punishment, banned for life into the market. On the other hand, egoist capital occupied a direct result of the legitimate interests of the company and other minority shareholders cannot be guaranteed. This behavior, ranging from the impact the share price, resulting in the loss of the company stakeholder interests, the weight is caused by the financial crisis, may lead the company into liquidation. Largest shareholder funds used to deal with problems caused by the self-interest, the need is to correct ideological aspects of big shareholders, and to be effective, rather than a mere formality regulation largest shareholder. While minority shareholders should actively protect their own interests, concerns a large shareholder action, within the company's shareholders to generate effective regulatory mechanisms to avoid damage to their own interests.

\section{CASE STUDY}

Qinghai Xiancheng Mining Company, previously known as Qinghai Xiancheng Industry Joint Stock Company, is a publicly-listed company listed on the Shanghai Stock Exchange. The Company's line of business includes distributing coal and other minerals and ores. It is also involved in the manufacture, sub-contract and sale of knitted and cottonspin products, purchasing wool materials, processing and selling of spinning machinery equipment parts. Its shares were listed on Shanghai Stock Exchange on May 8, 2001 under code 600381. The Company has reported losses for two consecutive years from 2005 to 2006 . In accordance with relevant regulations, the Company's stock was put under the category of special treatment of delisting risk warning from May 8, 2007. The daily price fluctuation was $5 \%$. The Company's A-share abbreviation was changed to '*ST XIANCHENG' with the stock code unchanged. In the event, the Company recorded losses in the year of 2007, and the Company's shares trading were terminated with effect. In 2007, the Company has reported profit. In accordance with relevant regulations, the Company has applied to the Shanghai Stock Exchange for removal of the special treatment of delisting risk warning on the Company's shares on April 23, 2008. Qinghai Sunshiny Industry Co., Ltd. (formerly known as Qinghai Xiancheng Co., Ltd.) is a publicly quoted company engaged in the development, management, operation and sale of real estate properties. It is also involved in the manufacture, sub-contract and sale of knitted and cotton-spin products, purchasing wool materials, processing and selling of spinning machinery equipment parts. Qinghai Sunshiny Industry Co., Ltd. was incorporated on August 28, 1998 with its head office in Xining, China.

Under the Guarantee Agreements, Qinghai Xiancheng provided guarantees on loans totaling RMB94.5 million, RMB159.5 million, RMB602.5 million and RMB565 million, in 2002, 2003, 2004 and 2005, respectively. Such guarantees were not disclosed in Qinghai Xiancheng's periodic reports filed pursuant to the PRC Securities Law. The CSRC instituted an investigation against Qinghai Xiancheng for the failure to disclose such guarantees provided by Qinghai Xiancheng. Following the investigation, the CSRC issued a censure against Qinghai Xiancheng and all members of the board of directors of Qinghai Xiancheng, including Mr. Huang. Mr. Huang and a number of the directors were also subject to a fine ranging from RMB30, 000 to RMB50, 000. The fund embezzlement of principal shareholders has a great effect on the company since it occurs in 2013 and the company has been in red. The growth capacity index in recent years and the histogram of sales revenue and gross profit is shown in Fig. 1. 


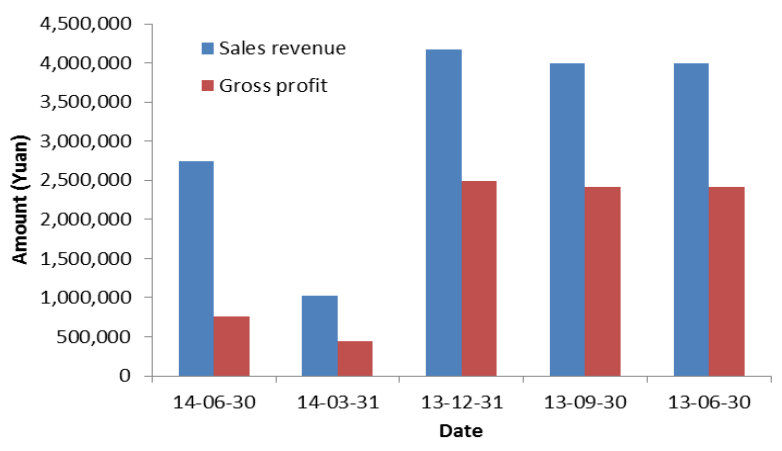

Fig. 1 Histogram of sales revenue and gross profit

\section{COUNTER-MEASURES OF EMBEZZLEMENT}

\section{A. External governance}

Increase penalties, strengthen supervision system, the largest shareholder funds used to reduce the occurrence of the root causes. Enhanced supervision of listed companies is necessary to put more effort thorough investigation of the existence of listed company funds occupancy issues, from "afterwards investigated" to "advance prevention" and "a matter of stop." The legislative branch should be punished with the introduction of relevant legal issues large shareholder funds used, while the Commission may consider giving administrative punishment, to enhance the inhibitory effect of large shareholders funds.

\section{B. Internal governance}

Large shareholders funds of the phenomenon of repeated to some extent with the internal control system are also relevant. Limited resources of small shareholders, and not the behavior of large shareholders to supervise, this way would require the company to the financial sector must be in strict accordance with the internal laws and regulations, adhere to the accounting professional ethics. Resolutely refused to unfair job requirements are the financial sector should observe the guidelines. At the same time, internal audit departments should perform their duties strictly within the company to review whether the funds used unfair question, dare to point out the problems in the company. Effective internal monitoring system will help reduce the occurrence of similar incidents, but also conducive to the healthy development of enterprises. Many companies are now occupied by the presence of large shareholders' funds phenomenon, largely with the relevant internal oversight system is not perfect. Many companies large shareholders but yes, even if they know the requirements of major shareholders and unreasonable, nor be firmly rejected demands for large shareholders, reckless violation of the relevant financial system, accounting system, hastily liquidity lent to large shareholders. Not only damage the interests of minority shareholders, but also for the company's normal operations increased obstacles. Internal oversight, internal audit is only a mere formality, only in the external supervision of independent and impartial review time, these problems will be found. It will be punished not only the Commission, but also the company is facing a crisis of confidence, running into a difficult situation.

\section{CONCLUSIONS}

The consequences and possible reasons for embezzlement of principal shareholders based on Xiancheng mining group were analyzed to uncover a high extent of operational tunneling in China. Some problems of external governance from China Securities Regulatory Commission and internal governance causing embezzlement of principal shareholders were pointed out. The study indicates that corporate governance could help to significantly improve internal and external governance structures and reduce tunneling. It is necessary and urgent to make legislation to prevent the embezzlement of principal shareholders and it is to make clear legal provisions to curb the idea of embezzlement of principal shareholders. Moreover, it is necessary for principal shareholders to realize that their own interests coincide with the interests of the company. It may bring temporary benefits from tunneling, but may cause long-term damage on the development of the company. Principal shareholders should be committed to make better development of the company and improve the company's competitiveness to obtain better prospects. Hence, economic reforms like the attempt to improve corporate governance and to limit the influence of the state in publicly listed companies are recommended and will help to further improve corporate governance principles in future.

\section{REFERENCES}

[1] Z. Li, Z. Wang, and Z. Sun, "Tunneling and ownership arrangement: empirical evidence from tunneling in Chinese listed firms," Journal of Accounting Research, vol. 25, pp. 3-13, 2004.

[2] S. C. Lindquist and S. R. Goldberg, "Embezzlement: Don't be a victim!," Journal of Corporate Accounting \& Finance, vol. 20, pp. 17-22, 2009.

[3] K. Wang and X. Xiao, "Controlling shareholders' tunneling and executive compensation: Evidence from China," Journal of Accounting and Public Policy, vol. 30, pp. 89-100, 1// 2011.

[4] W. Q. Peng, K. J. Wei, and Z. Yang, "Tunneling or propping: Evidence from connected transactions in China," Journal of Corporate Finance, vol. 17, pp. 306-325, 2011.

[5] G. Jiang, C. M. Lee, and H. Yue, "Tunneling through intercorporate loans: The China experience," Journal of Financial Economics, vol. 98, pp. 1-20, 2010.

[6] A. Shleifer and R. W. Vishny, "Large shareholders and corporate control," The Journal of Political Economy, pp. 461-488, 1986.

[7] S. Johnson, P. Boone, A. Breach, and E. Friedman, "Corporate governance in the Asian financial crisis," Journal of financial Economics, vol. 58, pp. 141-186, 2000.

[8] J. Wurgler, "Financial markets and the allocation of capital," Journal of financial economics, vol. 58, pp. 187-214, 2000.

[9] M. Bertrand, P. Mehta, and S. Mullainathan, "Ferreting out tunneling: An application to Indian business groups," National Bureau of Economic Research2000. 